\title{
Clearance and retention efficiency of natural suspended particles by the rock-pool bivalve Venerupis corrugatus in relation to tidal availability
}

\author{
J. M. E. Stenton-Dozey, A. C. Brown \\ Zoology Department, University of Cape Town, Rondebosch 7700, South Africa
}

\begin{abstract}
The natural spectrum of food particles available to, and used by, the burrowing clam Venerupis corrugatus (Gm.) was studied under contrasting weather conditions: prevailing SE wind in summer and a NE wind in winter. Seawater samples, collected hourly during a 13 h spring tidal cycle from a rock/sand pool, were analysed for particle size range (including bacteria), particulate quantity (counts, total and organic dry wt) and quality (organic content). Particle numbers increased on the flood tide, especially those $<4 \mu \mathrm{m}$ in diameter which rose 15 -fold. Furthermore maximum particle size increased from $12 \mu \mathrm{m}$ at low tide to $23 \mu \mathrm{m}$ at high tide, while total particulate dry weight increased 3 to 4 -fold to a maximum of $23 \mathrm{mg} \mathrm{l}^{-1}$. However total particulate dry weight never differed by more than 1.5 -fold between sampling occasions. At low tide $V$. corrugatus filtered out particles of 5 to $9 \mu \mathrm{m}$ at maximum rates of 2.3 to $3.1 \mathrm{l} \mathrm{h}^{-1} \mathrm{~g}^{-1}$; particle retention efficiencies were 70 to $100 \%$. At high tide particles of 8 to $13 \mu \mathrm{m}$ were cleared at the fastest rates ( 3.2 to $4.4 \mathrm{l} \mathrm{h}^{-1} \mathrm{~g}^{-1}$ ) and retained with efficiencies between 75 and $100 \%$. Possible mechanisms for these reponses are discussed. Such feeding behaviour enabled $V$. corrugatus to increase gross ingestion of organic material by $65 \%$ at high tide; even when pseudofaeces production was considered, net organic intake at high tide was still $39 \%$ above that at low tide. $V$. corrugatus appears to make maximum use of a natural resource whose supply is predictable with respect to tidal cycles, but highly variable in terms of particle size spectra, quantity and quality.
\end{abstract}

\section{INTRODUCTION}

The effects of food concentration on rates of particle clearance by marine bivalves are well researched, resulting in extensive reviews by Bayne (1976), Winter (1978), Bayne \& Newell (1983) and Griffiths \& Griffiths (1987). A monocultured alga suspended in filtered seawater was the most common food material used in early feeding experiments, simply because laboratory stocks provided a controlled and conveniently accessible source. Moreover, a single algal species presented a known and limited particle size spectrum which simplified measuring the decline in cell numbers and subsequent calculation of clearance rates.

Recent literature has clearly shown that establishing a relationship between clearance rate and algal concentration in the laboratory provides little insight into the feeding dynamics of bivalves in their natural environments. There is now greater emphasis on simulating particulate material found in the field by considering particle size spectra and food quality and, more recently, temporal and spatial influences.

Simulation of natural particle sizes has involved mixing suspensions of cultured algae, sometimes in combination with bacteria (Bayne et al. 1984, Stuart \& Klumpp 1984, Cucci et al. 1985, Shumway et al. 1985. Amouroux 1986). In considering food quality, natural silt has been combined with cultured algae to vary the calorific value as well as organic, carbon and nitrogen content of suspended particles (Kiorboe \& Møhlenberg 1981, Kiørboe et al. 1981, Møhlenberg \& Kiørboe 1981, Newell \& Jordan 1983, Bricelj \& Malouf 1984, Robinson et al. 1984, Bayne et al. 1987, 1989, de Villiers \& Allanson 1988). A more relevant simulation 
has been the use of natural materials from a bivalve's habitat, such as powdered saltmarsh leaves (Lucas \& Newell 1984, Newell \& Langdon 1986) and detritus derived from kelp fronds (Stuart 1982). However, the most meaningful feeding experiments to date have been those employing unfiltered seawater collected from the natural environment (Wright et al. 1982, Newell \& Jordan 1983, Lucas et al. 1987, Matthews et al. 1989). Such experiments provide natural food quantity and quality as well as features such as texture and palatability which are virtually impossible to mimic in the laboratory.

Within the scope of bivalve nutrition, research relating laboratory feeding data to natural patterns of food availability is scarce. Work undertaken in this regard has focused on varying experimental concentrations of particulates in association with seasonal fluctuations in the field (Griffiths \& King 1979, Griffiths 1980, Hawkins \& Bayne 1984, 1985, Bayne et al. 1987) or, in the shorter term, with episodic events such as upwelling and downwelling (Stuart \& Klumpp 1984, Seiderer \& Newell 1985). Besides these temporal considerations, some attention has been given to spatial effects by comparing the feeding behaviour of individuals from separate populations of the same species which inhabit contrasting environments and consequently experience different food sources (Bayne et al. 1984, Lucas et al. 1987. Clarke \& Griffiths 1990). Although many of these workers recognised that in nature there must be temporal and spatial differences in food quality, only Hawkins \& Bayne (1985) and Bayne et al. (1987) considered this aspect in feeding experiments. They researched seasonal patterns of food processing by Mytilus edulis in terms of carbon, nitrogen and seston content of natural particulates at different times of the year. Their data indicated endogenous regulation of pronounced seasonal variation in absorption. This led to the important suggestion that maximisation of net energy balance may only be optimal in 'some time-averaged sense' rather than in the short term (Hawkins et al. 1985).

The aim of the present study was to investigate the natural spectrum of food particles available to and used by the burrowing, filter-feeding clam Venerupis corrugatus (formerly Tapes corrugatus [Gm.]). This species is found along the southern African coastline from Luderitz to Port Elizabeth (Day 1974) and inhabits protected sandy areas such as are found in lagoons and between rocks in intertidal rock pools. Fluctuations in food supply in a rock pool were considered by measuring particulate quantity (numbers and mg dry weight) and quality (organic content) every hour over a $1.3 \mathrm{~h}$ spring tidal cycle on 2 separate occasions when weather conditions were markedly different. To demonstrate realistically the feeding behaviour of
$V$. corrugatus in its own environment, only natural particles at concentrations recorded in the field over a tidal cycle were used when measuring feeding rates.

\section{MATERIALS AND METHODS}

Rock-pool environment. The study site was located at Bloubergstrand, just north of Cape Town, on the west coast of South Africa, and comprised a large rock pool (approximate surface area $170 \mathrm{~m}^{2}$ ) formed of sand and rock. At low tide the pool is isolated from the sea by a rocky outcrop, beyond which lies an extensive kelp bed. Besides Venerupis corrugatus, the most common molluscan filter-feeders in the pool are Mytilus galloprovincialis and Choromytilus meridionalis.

Rock-pool water samples were collected at hourly intervals over a $13 \mathrm{~h}$ spring tidal cycle, with low tides occurring at about 8:00 and 20:00 $h$ and high tide between 11:00 and 12:00 h. Samples were processed either on site or immediately on return to the laboratory. Sampling was undertaken when a strong onshore northwest wind, typical of downwelling conditions, prevailed in winter and again at the time of an offshore, gale-force $\left(50 \mathrm{~km} \mathrm{~h}^{-1}\right)$ southeast wind indicative of upwelling in summer.

Temperature and oxygen content were also monitored every hour. When the NW wind prevailed, temperatures remained stable around $15{ }^{\circ} \mathrm{C}$ over the $13 \mathrm{~h}$ tidal cycle. With a SE wind blowing, however, water warmed up from 13 to $18^{\circ} \mathrm{C}$ while the pool was isolated, falling to $14^{\circ} \mathrm{C}$ after inundation. Generally oxygen levels were lower with a NW wind (5 to $9 \mathrm{mg} \mathrm{l}^{-1}$ ) than with a SE wind (8 to $10 \mathrm{mg} \mathrm{l}^{-1}$ ). Irrespective of wind direction however, $\mathrm{O}_{2}$ content reached supersaturation on the incoming tide.

Sample analysis. Immediately after collection, all water samples were passed through a $100 \mu \mathrm{m}$ sieve. Those destined for analysis of particulate dry weight were partially processed on site. Six $500 \mathrm{ml}$ samples of rock-pool water were filtered through ashed $\left(460^{\circ} \mathrm{C}\right.$ for $6 \mathrm{~h}$ ), pre-weighed $25 \mathrm{~mm}$ Whatman GF/F filters and finally rinsed with isotonic ammonium formate under vacuum to remove salts. These filters were dried at $60^{\circ} \mathrm{C}$ for $2 \mathrm{~d}$ to obtain total dry weight, then ashed at $460^{\circ} \mathrm{C}$ for $20 \mathrm{~h}$, reweighed, and organic content of suspended particulates determined by difference.

In the laboratory, particles were counted in triplicate for each sampling occasion on a Coulter Multisizer, using a $70 \mu \mathrm{m}$ aperture tube which covered a particlediameter range of 1.5 to $45 \mu \mathrm{m}$. Particle numbers and dry weight were assessed according to $1 \mu \mathrm{m}$ diameter size categories. Dry weight per size category was calculated as the product of total dry weight and particle volume per size category. This approach necessitated 
assuming that neither density nor organic content varied with particle size. In support of this assumption, microscopic examination of rock-pool filtrate indicated that, irrespective of particle size, material composition of particulates appeared the same. A 3-dimensional plotting programme 'Surfer' (Golden Software, Inc.) was used to depict the fluctuations in number and dry weight per size category in relation to tidal cycle for the NW and SE wind conditions.

Since bacterial-sized particles $(<1 \mu \mathrm{m})$ were excluded from Multisizer counts, free-living bacteria were enumerated separately by the AODC technique of Hobbie et al. (1977). For every hour in the field, two $10 \mathrm{ml}$ water samples were placed in autoclaved vials with $1 \mathrm{ml}$ gluteraldehyde and later stored at $<4^{\circ} \mathrm{C}$. Two $5 \mathrm{ml}$ aliquots were filtered onto membrane filters and, for each, bacteria were counted in 30 microscopic fields. Bacteria were classified into 6 morphotypes (Painting et al. 1985), whose dimensions and relative abundance yielded weighted mean spherical diameters. These were used to calculate bacterial biomass based on a weighted mean cell volume, a specific gravity of $1.1 \mathrm{~g} \mathrm{~cm}^{-3}$ (Luria 1960, Doetsch \& Cook 1973, Linley et al. 1981) and a dry-wet ratio of 0.2 (Luria 1960).

Estimation of clearance rate. Experimental clams were collected from Bloubergstrand in summer when a light SE wind prevailed. At the same time, 50 l of rockpool water was sampled at low and high tides, when low and high particle densities could respectively be expected based on previous sampling experience. Clams were maintained in rock-pool water overnight so that they could feed on natural particulates before experiments were conducted the following day. Repetition of experiments when a NW wind prevailed was not undertaken since particulate availability, as well as physico-chemical parameters (unpubl. data), differed little from those of samples collected at the time of a SE wind. Thus, in terms of the influence of particle concentration on clearance rates, there was little likelihood of identifying a significant effect related to the weather pattern.

Twenty Venerupis corrugatus were placed separately in beakers with $1.5 \mathrm{l}$ of either low-or high-tide rock-pool water that had been passed through a $100 \mu \mathrm{m}$ sieve. Specimens ranged in size from 17 to $53 \mathrm{~mm}$ shell length $(11$ to $33 \mathrm{~mm}$ shell width; 26 to $867 \mathrm{mg}$ dry tissue weight). For each set of experiments, 2 beakers with seawater but no animals served as controls. Water was aerated and circulated by air-lift pumps and maintained at $15^{\circ} \mathrm{C}$, the average temperature in the rock pool over a tidal cycle.

Clearance rates were determined indirectly by measuring the decline in particle densities over consecutive $20 \mathrm{~min}$ periods for a total of $100 \mathrm{~min}$. At the beginning and end of each 20 min period, particles of $>1$ but $<30 \mu \mathrm{m}$ diameter were counted in triplicate within $1 \mu \mathrm{m}$ diameter size classes. At the same time bacteria were enumerated using methods described earlier. After correcting for particle decline in controls, mean particle concentrations were used in the equations of Coughlan (1969) to calculate clearance rate per individual per $1 \mu \mathrm{m}$ size fraction over a period of 20 min. Rates from each 20 min period were meaned and finally expressed as $1 \mathrm{~h}^{-1}$ for an individual of $1 \mathrm{~g}$ dry tissue weight using a weight exponent of 0.62 (Stenton-Dozey \& Brown unpubl.). Model I 2-way factorial ANOVA and Student Newman-Keuls (SNK) multiple comparison analysis (Zar 1984) were used to determine variability in data and significant differences in feeding rates that could be related to particle size or/and weather condition.

Relative particle retention efficiency. A retention efficiency of $100 \%$ was assumed to occur for particles cleared at the highest rate over the spectrum from bacteria to $30 \mu \mathrm{m}$ diameter. All other retention efficiencies were expressed as a percentage of this maximum rate.

Resource availability and utilisation. Food availability during experiments was expressed as total and organic dry weight per particle size class. This was estimated as the product of total particle mass and the relative volume of particles in each size category. Utilisation of a specific sized resource, i.e. ingestion as $\mathrm{mg} \mathrm{h}^{-1}$, was calculated as (resource availability, $\mathrm{mg} \mathrm{l}^{-1}$ ) $\times$ (mean clearance rate, $1 \mathrm{~h}^{-1}$ ) $\times$ (relevant retention efficiency, \%). This method of calculating ingestion rates precluded the application of statistical analysis of variability in, and significant differences among, data.

Gross ingestion estimates had to be corrected for particulates rejected at the gills and labial palps and released as pseudofaeces during experiments. This was achieved by subtracting the mean total and organic dry weight of pseudofaeces produced $\mathrm{h}^{-1}$ from the overall quantity of material ingested. Net or actual ingestion was then recalculated for each size category using the relevant particle volume once again. This approach assumes that no specific particle size was preferentially rejected in the pseudofaeces.

\section{RESULTS}

\section{Tidal variation in potential resource availability}

Proportional densities of the different bacterial morphotypes, together with their weighted mean diameters, are presented in Table 1. Numerical composition was dominated $(>79 \%)$ by small cocci, large cocci and small rods, irrespective of tidal height 
Table 1. Biomass and numerical composition (\%) of different rock-pool bacterial morphotypes over a $13 \mathrm{~h}$ tidal cycle when NW and SE winds prevailed at Bloubergstrand. These data were used to calculate weighted mean diameters for each weather condition based on the morphological characteristics described by Painting et al. (1985)

\begin{tabular}{|c|c|c|c|c|c|c|c|}
\hline \multirow[t]{2}{*}{ Morphotype } & \multirow{2}{*}{$\begin{array}{c}\text { Mean } \\
\text { spherical } \\
\text { diameter } \\
(\mu \mathrm{m})\end{array}$} & \multicolumn{3}{|c|}{ Northwest wind } & \multicolumn{3}{|c|}{ Southeast wind } \\
\hline & & $\begin{array}{c}\text { Mean } \\
\text { biomass } \\
\text { composition } \\
(\%)\end{array}$ & $\begin{array}{c}\text { Mean } \\
\text { numerical } \\
\text { composition } \\
(\%)\end{array}$ & $\begin{array}{c}\text { Weighted } \\
\text { mean } \\
\text { diameter } \\
(\mu \mathrm{m})\end{array}$ & $\begin{array}{c}\text { Mean } \\
\text { biomass } \\
\text { composition } \\
(\%)\end{array}$ & $\begin{array}{c}\text { Mean } \\
\text { numerical } \\
\text { composition } \\
(\%)\end{array}$ & $\begin{array}{c}\text { Weighted } \\
\text { mean } \\
\text { diameter } \\
(\mu \mathrm{m})\end{array}$ \\
\hline Small cocci & 0.25 & 1.16 & 21.06 & 0.053 & 1.03 & 18.00 & 0.045 \\
\hline Large cocci & 0.56 & 18.25 & 18.10 & 0.101 & 21.16 & 23.61 & 0.132 \\
\hline Small rods & 0.73 & 49.88 & 40.66 & 0.295 & 58.19 & 46.50 & 0.337 \\
\hline Large rods & 1.15 & - & - & - & - & - & - \\
\hline Small U-shaped & 0.73 & 17.88 & 12.48 & 0.091 & 9.92 & 7.91 & 0.057 \\
\hline S-shaped & 0.73 & 2.93 & 2.32 & 0.017 & 5.09 & 1.70 & 0.012 \\
\hline \multirow[t]{2}{*}{ Dividing } & 0.36 & 9.91 & 5.38 & 0.020 & 4.60 & 2.40 & 0.009 \\
\hline & & & & 0.576 & & & 0.592 \\
\hline
\end{tabular}

or prevailing wind direction. In terms of biomass, small rods made the largest contribution (50 to $58 \%$ ). Since such bacteria have the largest spherical diameter (0.73 $\mu \mathrm{m}$; Painting et al. 1985) and hence greater potential for being retained by the gills of Venerupis corrugatus, they may be of notable nutritional value. The weighted mean diameter of bacteria was not influenced by weather condition, being nearly identical at $0.576 \mu \mathrm{m}$ during the northwesterly, and $0.592 \mu \mathrm{m}$ with SE winds.

Variation in total bacterial numbers and biomass over a spring tidal cycle is presented in Fig. 1. Bacteria were most plentiful (up to $2.5 \times 10^{9} \mathrm{l}^{-1}$ ) in samples collected prior to tidal flooding when a NW wind blew. Once rock-pool and nearshore water mixed bacterial abundance dropped to $0.7 \times 10^{9} \mathrm{l}^{-1}$. During the SE wind a different tidal-response pattern was observed. Numbers were generally lower $\left(0.5\right.$ to $\left.1.0 \times 10^{9} \mathrm{l}^{-1}\right)$ throughout the tidal cycle, except immediately after water entered the pool, when counts doubled. This pattern seems to indicate that rock-pool bacteria were temporarily brought into greater suspension on tidal inundation, an effect that was lost, however, once nearshore and pool waters were thoroughly mixed.

Three-dimensional representation of tidal variation in different particle sizes in the range 1 to $30 \mu \mathrm{m}$ is shown in Fig. 2. Particle abundance was greatest in the fraction less than 8 to $10 \mu \mathrm{m}$ in diameter, whereas dry weight maxima covered a wider range from 1 to $20 \mu \mathrm{m}$. A pronounced increase in suspended material occurred on the flood tide, especially within the $<4 \mu \mathrm{m}$ numerical fraction which increased 15-fold. In the range 4 to $15 \mu \mathrm{m}$, the rise in particle numbers was greater when the SE wind was blowing. Tidal variation in the total number and dry weight particle spectra presented in Fig. 2 is glven in Fig. 3. Under SE wind conditions numbers doubled (to $200 \times 10^{\mathrm{t}} \mathrm{I}^{-1}$ ) on flooding and with a northwesterly blowing, the corresponding increase was 1.5 times (to $150 \times 10^{6} \mathrm{1}^{-1}$ ).

When using organic content as an indicator of particulate quality, small tidal and weather-related differences were apparent (Fig. 3). Organic material was generally 20 to $30 \%$ more abundant when the northwest wind prevailed. Tidal inundation resulted in a decline in the organic content of particulates sus-
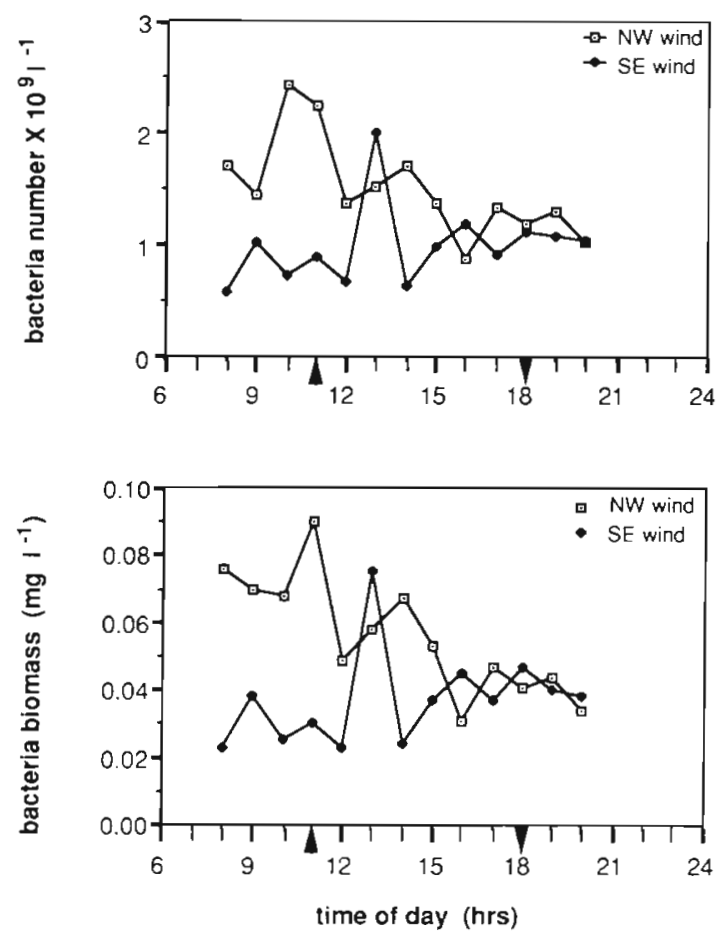

Fig. 1. Tidal variation in bacterial numbers and biomass in the rock pool when 2 contrasting weather conditions prevailed, a NW wind in winter and a SE wind in summer. Arrow at 11:00 h: tidal flooding; arrow at 18:00 h: isolation of the pool on the ebb tide 
A. NORTH-WEST WIND
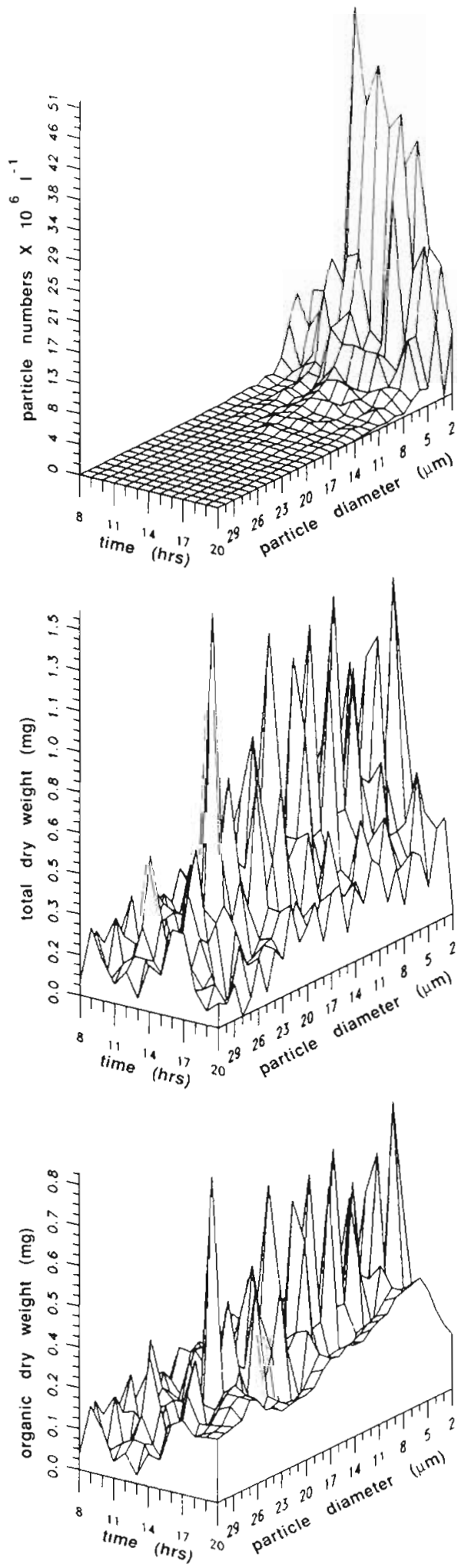

B. SOUTH-EAST WIND
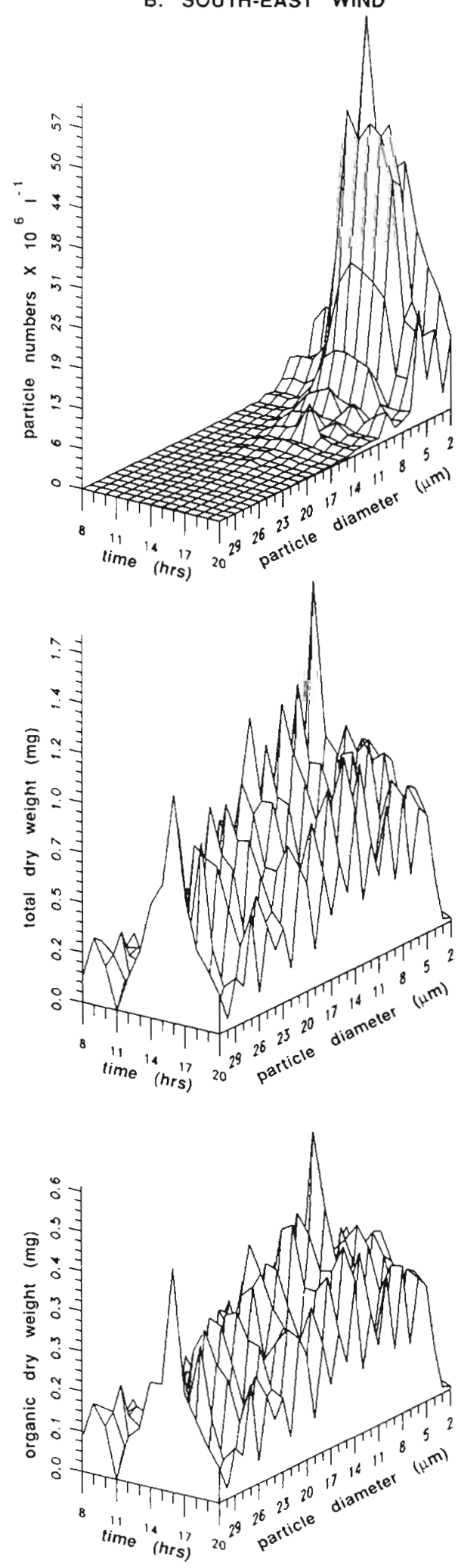

Fig. 2. Three-dimensional representation of tidal variation in particle numbers and dry weight (mg total and organic) per $1 \mu \mathrm{m}$ particle size category at the time of (A) a NW wind in winter, and (B) a SE wind in summer. Particle diameters ( $\mu \mathrm{m}$ ) were plotted as median values of each $1 \mu \mathrm{m}$ size category 

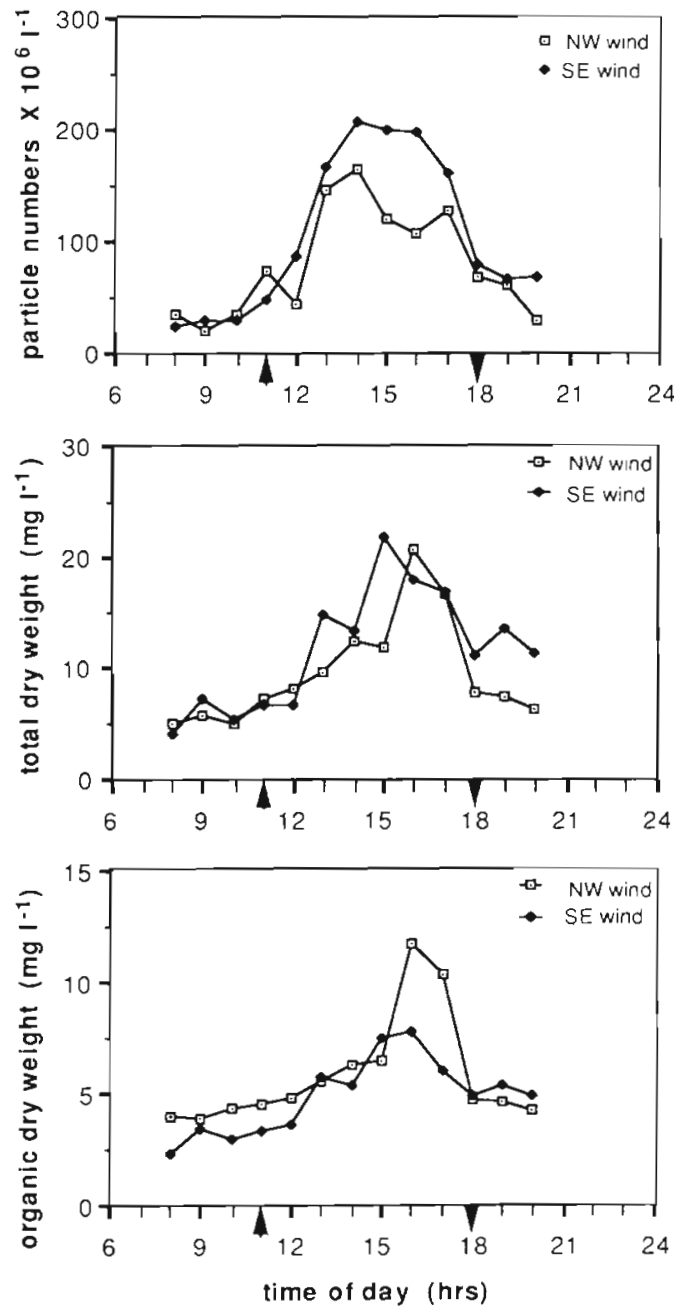

Fig. 3. Tidal variation in numbers, and total and organic dry weight of particulates in the rock pool when a NW and SE wind prevailed (arrows as in Fig. 1)

pended in the rock pool. In NW-wind samples the organic portion fell from 90 to $50 \%$ on flooding compared with a decline from 60 to $30 \%$ in samples collected during a SE wind.

\section{Resource availability during feeding experiments}

The quantity of particulates potentially available for exploitation as a food resource by Venerupis corrugatus in feeding experiments with natural water is illustrated in Fig. 4 as numbers and total or organic dry weight $l^{-1}$ per $1 \mu \mathrm{m}$ diameter size class up to $23 \mu \mathrm{m}$. Data are from samples collected during low tide and when the pool was flooded at high tide

Of the total particulate suspension present at low tide, bacteria with a mean spherical diameter of $0.639 \mu \mathrm{m}$ were most numerous. Although they comprised $98 \%$ of the overall number $\left(3397 \times 10^{6} \mathrm{l}^{-1}\right)$, contribution to total dry weight $\left(6.7 \mathrm{mg}^{-1}\right.$ of which $61 \%$ was organic) was only ca $2 \%$. Excluding bacteria, particulates were most abundant within the 1 to $2 \mu \mathrm{m}$ diameter size class $\left(29 \times 10^{6} \mathrm{I}^{-1}\right)$ whereas biomass peaked between 4 and $6 \mu \mathrm{m}$ and again between 10 and $12 \mu \mathrm{m}$. There were virtually no particles $>12 \mu \mathrm{m}$.

Particulate concentrations during the flood tide were higher (Fig. 4) with a total numerical resource of $5595 \times 10^{6} \mathrm{l}^{-1}$ yielding $9.6 \mathrm{mg} \mathrm{l^{-1 }}$. Organic content was lower $(53 \%)$ and thus, in terms of total organic dry weight, the amount of material at high tide was only 1 $m g l^{-1}$ more than at low tide. Free-living bacteria still dominated abundance $(96 \%)$ but comprised only a small part of biomass (ca $2 \%$ ). Furthermore, particles other than bacteria were still most abundant in the 1 to $2 \mu \mathrm{m}$ size category, although the maximum number reached was 5 times that when the tide was out. The size spectrum, however, covered a greater range, up to $23 \mu \mathrm{m}$. This indicates that a greater proportion of large particles was either carried in by the flood tide or more of those already in the pool were brought into suspension by tidal turbulence. This resulted in high biomass values for all particle sizes $>7 \mu \mathrm{m}$ as well as there being no sharply discernible maximum for any one particular size category. In relative terms therefore, the particle sizes which dominated biomass shifted from between 3 and $8 \mu \mathrm{m}$ at low tide to those $>7 \mu \mathrm{m}$ at high tide. This trend was to some extent also evident in the 3-D plots in Fig. 2.

\section{Resource utilisation}

Given the particle size range in water collected at low tide (Fig. 4), clearance rates could only be determined for particles up to $12 \mu \mathrm{m}$ in diameter. High tide rates could only be reliably determined up to the $17 \mu \mathrm{m}$ size class even though the spectrum available reached $23 \mu \mathrm{m}$. The scarcity of large particles (see Fig. 4) made calculation of numbers cleared from suspension unreliable when using the equations of Coughlan (1969).

Clearance rates of particles within the above size ranges and within $1 \mu \mathrm{m}$ diameter fractions are represented as means \pm 2 SE's in Fig 5 whilst the results of performing a Model I 2-way factorial ANOVA on these data are given in Table 2. Also included in Fig. 5 are the results of SNK multiple comparison tests used to identify particle sizes cleared at rates not significantly different from each other at either low or high tide.

ANOVA indicated that clearance rates were significantly affected by both tidal height and particle size as well as by an interaction of these 2 factors (Table 2). Subsequent SNK tests revealed that irrespective of 

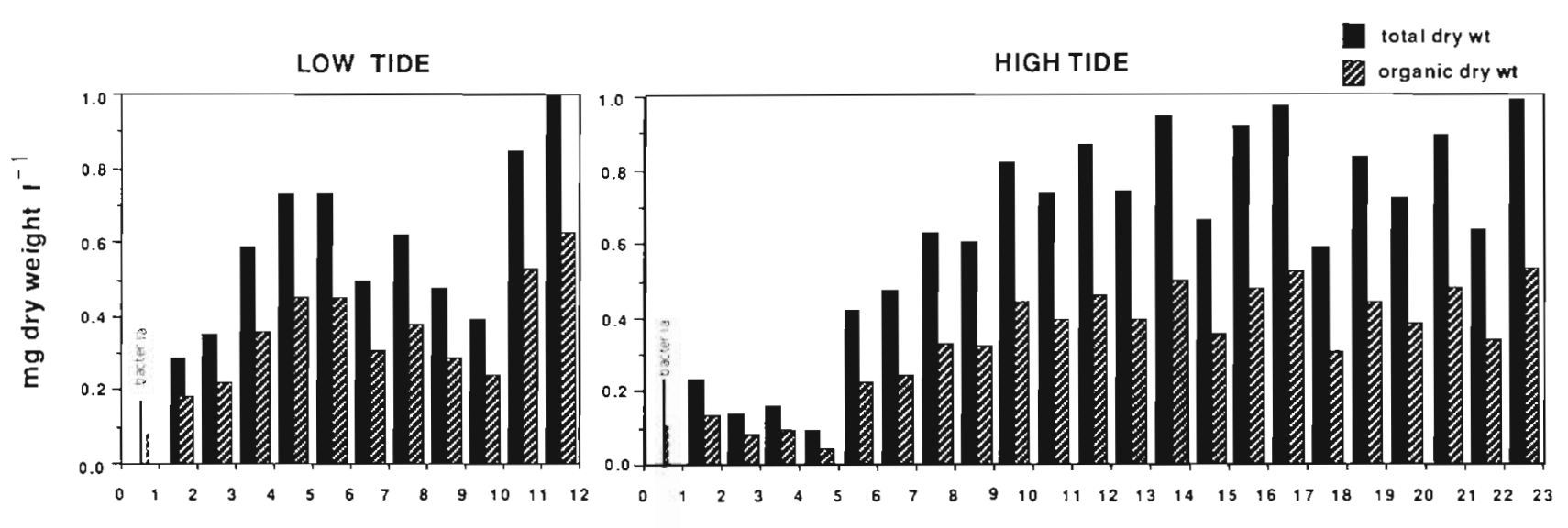

LOW TIDE
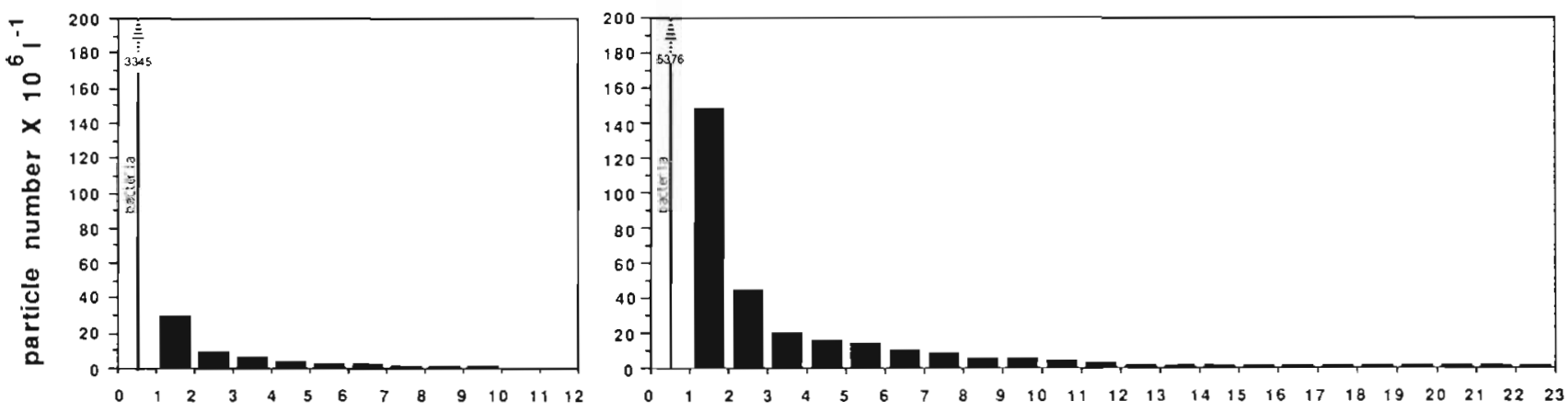

particle size classes ( $\mu \mathrm{m}$ diameter)

particle size classes ( $\mu \mathrm{m}$ diameter)

Fig. 4. Quantity of particulates potentially available for exploitation as a food resource by Venerupis corrugatus. Data are expressed in numbers $\left(\times 10^{6}\right)$ and total or organic dry weight $\left(\mathrm{mg} \mathrm{l}^{-1}\right)$ per $1 \mu \mathrm{m}$ size category. Organic weight was calculated using a total:organic ratio of 0.61 and assuming the same for all particle sizes. At low tide there were few particles $>12 \mu \mathrm{m}$ in diameter and hence, for clarity, this size fraction has been omitted

tidal height, certain particle sizes, namely within the fractions $<1,2$ to 3 and 5 to $8 \mu \mathrm{m}$ in diameter, were cleared at rates which showed no significant differences.

According to SNK tests represented in Fig. 5, at low tide particles of 5 to $9 \mu \mathrm{m}$ in diameter were cleared at rates which were maximum between 2.3 and $3.1 \mathrm{l} \mathrm{h}^{-1} \mathrm{~g}^{-1}$ ) and which showed no significant differences. Minimum clearance coincided with particles $<3 \mu \mathrm{m}\left(0.5\right.$ to $\left.0.9 \mathrm{l} \mathrm{h}^{-1} \mathrm{~g}^{-1}\right)$ while those within the 9 to $12 \mathrm{~mm}$ fraction were filtered at intermediate rates (ca $2 \mathrm{l} \mathrm{h}^{-1} \mathrm{~g}^{-1}$ ) (Fig. 5). Corresponding relative retention efficiencies are shown in Fig. 6. According to assumptions made earlier (see 'Materials and methods'), maximum clearance rates at low tide resulted in particles between 5 and $9 \mu \mathrm{m}$ diameter being retained with 70 to $100 \%$ efficiency. Above $9 \mu \mathrm{m}$ diameter retention efficiencies declined to some $60 \%$, although intuitively one may expect that any particle larger than the optimal size $(9 \mu \mathrm{m})$ would also be retained with $100 \%$ efficiency. This is probably so, but as already mentioned, a resource of large but few particles makes it difficult to measure clearance rates accurately. Thus rates could have been underestimated in this size fraction.

At high tide, particles between 8 and $13 \mu \mathrm{m}$ were cleared at the fastest, non-significantly different rates of 3.2 to $4.4 \mathrm{l} \mathrm{h}^{-1} \mathrm{~g}^{-1}$ (Fig. 5) and retained with efficiencies between 75 and $100 \%$ (Fig. 6). Once again there was an apparent decline in the removal (ca $2 \mathrm{I} \mathrm{h}^{-1} \mathrm{~g}^{-1}$ ) and retention (ca $40 \%$ ) of particles larger than $13 \mu \mathrm{m}$. At the lower end of the spectrum $(<4 \mu \mathrm{m}$ including bacteria), clearance rates approximated only $1 \mathrm{l} \mathrm{h}^{-1} \mathrm{~g}^{-1}$ with a corresponding 20 to $30 \%$ retention efficiency.

The most striking feature of these data was the increase in clearance rate at high tide when there was a greater abundance of particles $>9 \mu \mathrm{m}$ in diameter Within the 5 to $9 \mu \mathrm{m}$ fraction there was no significant difference between clearance rates at low and high tide (Table 2). Above this size category, however, clearance rates reached maxima not witnessed over 
LOW TIDE

HIGH TIDE

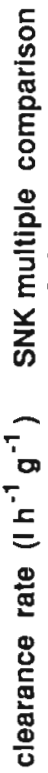

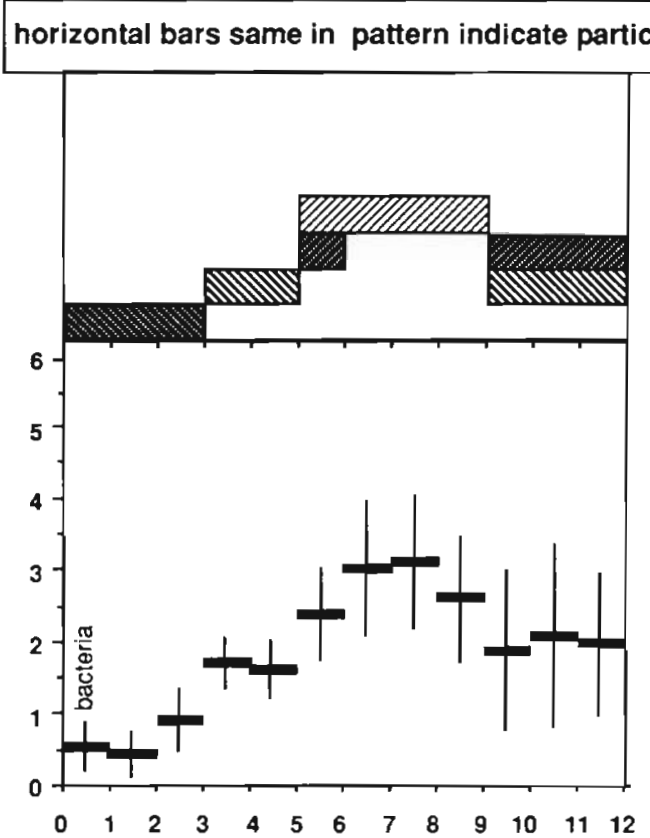

sizes cleared at rates not significantly different from each other

particle size classes ( $\mu \mathrm{m}$ diameter)

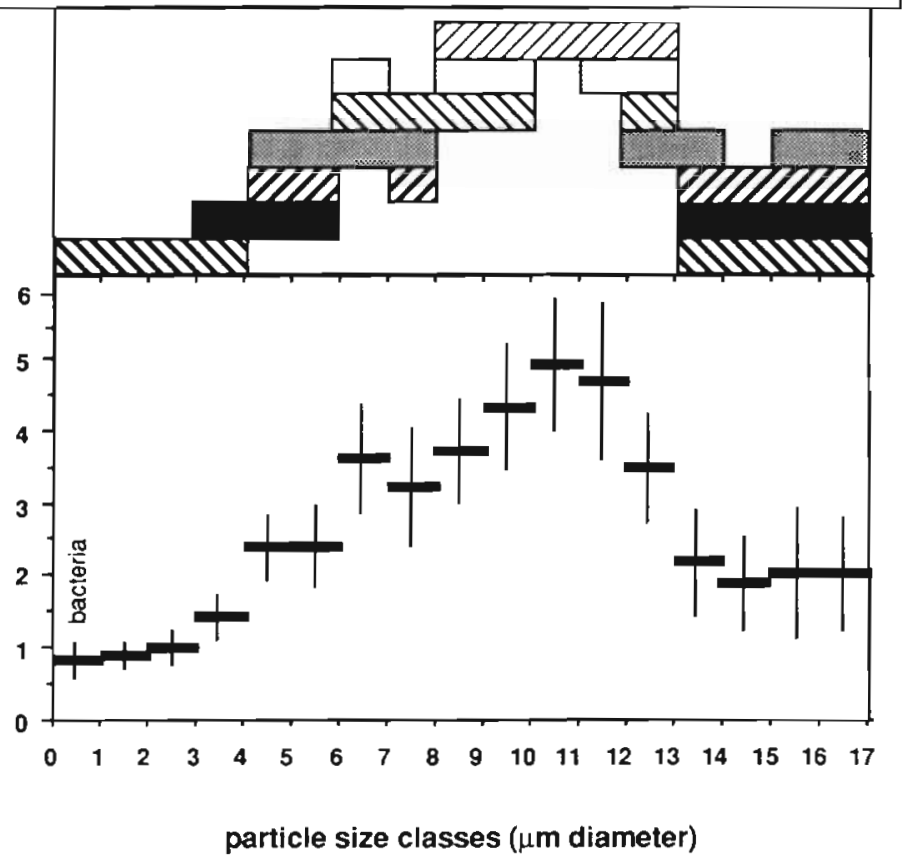

Fig. 5. Diagrammatic representation of Student Newman-Keuls multiple comparison analyses showing particle sizes up to $17 \mu \mathrm{m}$ diameter that are cleared at rates not significantly different from one another. Clearance rates are represented as means $\pm 2 S E$ 's.

Confidence limits were set at $95 \%$ and statistical procedures followed Zar (1984)

Table 2. Model I 2-way factorial ANOVA for clearance rates $\left(\mathrm{CR}_{i} \perp \mathrm{h}^{-1} \mathrm{~g}^{-1}\right)$ by Venerupis corrugatus of particles within $1 \mu \mathrm{m}$ diameter size classes during low and high tide. Tidal height was treated as 2 levels in Factor $\mathrm{A}$ and particle size as 12 levels (range 0 to $12 \mu \mathrm{m}$ ) in Factor B (after Zar 1984). Subsequently SNK tests were used to identify significant differences in CR relating to particle size and/or tidal height (see text and Fig. 5)

\begin{tabular}{|lrrr}
\hline Source of variation & SS & df & MS \\
\hline Total & 921.237 & 407 & \\
Cells & 804.438 & 23 & \\
Factor A (tidal height) & 11.532 & 1 & 11.532 \\
Factor B (particle size) & 407.292 & 11 & 37.027 \\
A $\times$ B & 385.614 & 11 & 35.056 \\
Within cells (error) & 116.799 & 384 & 0.304
\end{tabular}

Null hypotheses:

For $H_{0}$ : There is no effect of tidal height on CR

$F=37.934 \quad F_{005(1) 1,384}=3.87$

Thus reject $H_{0} \quad p<0.0005$

For $H_{0}$ : There is no difference in $C R$ of different particle sizes

$$
\begin{array}{ll}
F=121.799 & F_{0051111384}=1.82 \\
\text { Thus reject } H_{0} & p<0.0005
\end{array}
$$

For $H_{0}$ : There is no interaction of tidal height \& particle size affecting $C R$

$$
\begin{array}{ll}
F=115.316 & F_{0.05(111) 384}=1.82 \\
\text { Thus reject } H_{0} & p<0.0005
\end{array}
$$

the particle size range present at low tide. Thus, within the period of one tidal cycle and within the particle size range of 5 to $13 \mu \mathrm{m}$, it appears that Venerupis corrugatus maximised filtration and retention efficiency of those particles that would yield the most food material per litre of rock-pool water (Figs. 4, 5 \& 6).

\section{Resource yield}

From mean clearance rates and retention efficiencies presented in Figs. $5 \& 6$ and data on resource availability in Fig. 4, the organic dry weight ingested by Venerupis corrugatus within each size fraction was calculated. This is shown in Fig. 7 as weight-specific gross and net organic yield ( $\mathrm{mg} \mathrm{h}^{-1} \mathrm{~g}^{-1}$ ). Net values take into account organic material that was ingested but then rejected as pseudofaeces.

At low tide, overall gross organic yield was $39 \%$ below that at high tide $\left(8.4\right.$ and $13.9 \mathrm{mg} \mathrm{h}^{-1} \mathrm{~g}^{-1}$ respectively) but as net values (5.7 and $7.9 \mathrm{mg} \mathrm{h}^{-1} \mathrm{~g}^{-1}$ ) the percentage difference was reduced to $27 \%$. Thus the rate of organic loss via pseudofaeces was less at low than high tide. This can be attributed to a higher particle concentration in water collected at flood tide in 


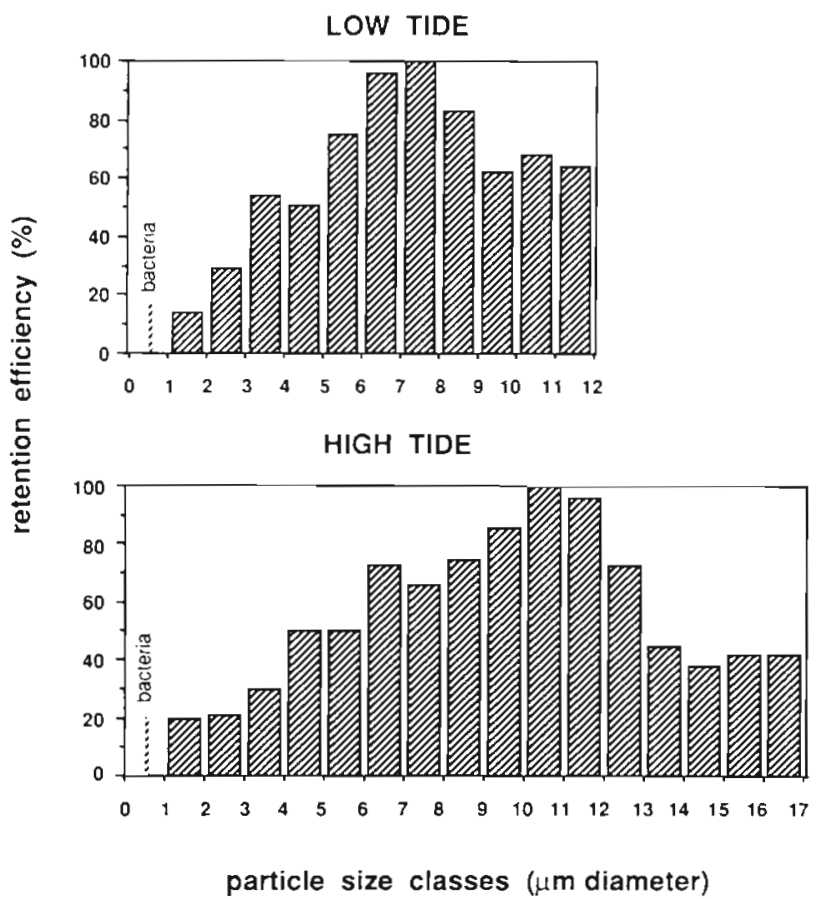

Fig. 6. Venerupis corrugatus. Relative retention efficiencies of particles within $1 \mu \mathrm{m}$ diameter categories (ranging in size from free-living bacteria to $17 \mu \mathrm{m}$ ) at low and high tide. A retention efficiency of $100 \%$ was assumed to conncide with maximum cladance rates

combination with faster clearance rates (Table 2) and a coincidental increase in rejection via pseudofaeces of material with potential food value.

In relation to the available particle spectrum at low tide, the 5 to $8 \mu \mathrm{m}$ and 10 to $12 \mu \mathrm{m}$ fractions yielded the greatest organic material to Venerupis corrugatus (66\% in all). The maximum ingestion rate (or yield) at low tide coincided with the 11 to $12 \mu$ m category, when a rate of $1.3 \mathrm{mg}$ organics $\mathrm{h}^{-1} \mathrm{~g}^{-1}$ with a net value of $0.9 \mathrm{mg} \mathrm{h}^{-1} \mathrm{~g}^{-1}$ was attained.

At high tide, ingestion rates were either similar to or greater than top rates at low tide over a wide range of particle sizes from around 7 to $14 \mu \mathrm{m}$ diameter. These particles provided $69 \%$ of the total gross and net organic yield to Venerupis corrugatus. Within this range, particles between 9 and $12 \mu \mathrm{m}$ were ingested at the fastest rates; nearly $2 \mathrm{mg}$ of organics was ingested by a $1 \mathrm{~g}$ clam $\mathrm{h}^{-1}$ and this provided a net intake of around $1 \mathrm{mg} \mathrm{h}^{-1} \mathrm{~g}^{-1}$.

At both high and low tide, bacteria comprised less than $0.7 \%$ of the total organic intake. At low tide the contribution of particles $>1$ but $<3 \mu \mathrm{m}$ was also minor $(<3 \%)$. The equivalent percentage contribution of small particles at high tide covered a wider size range, from 1 to $5 \mu \mathrm{m}$. In relative terms, therefore, smaller particles within a restricted size range were ingested
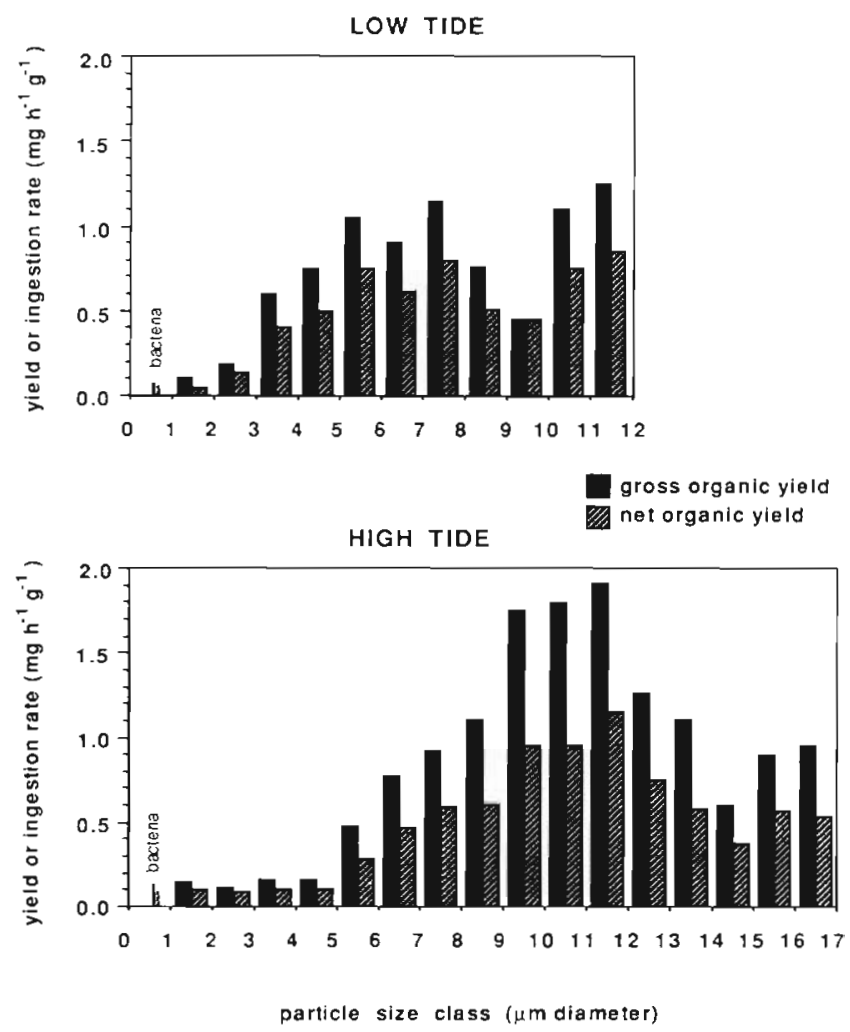

Fig. 7 Venerupis corrugatus. Weight-specific gross and net organıc dry weight yield ( $\mathrm{mg} \mathrm{h}^{-1} \mathrm{~g}^{-1}$ ) based on mean clearance rates (Table 2, Fig. 5) and retention efficiency of particles $<17 \mu \mathrm{m}$ (Fig. 6) at low and high tide in the rock pool. Net yield was obtained after subtractıng the organic fraction in material rejected as pseudofaeces

at low tide; when the pool was flooded, larger particles spanning a wider range were favoured.

\section{DISCUSSION}

Data clearly indicate that the availability of natural particulates to Venerupis corrugatus inhabiting an intertidal rock pool was more strongly influenced by tidal cycles than prevailing weather conditions. The amount of food, expressed as dry weight of free living bacteria and other suspended particles, fluctuated 3- to 4 -fold between rise and fall of the tide compared to only 1.5 -fold between the 2 weather conditions. Food quality, although predominantly influenced by tide, was higher during the NW than SE wind conditions in terms of the proportion of organic material.

Differences in particulate quality related to the weather condition may, to some extent, be a consequence of episodic up-and down-welling events on the southwest coast of South Africa (Newell et al. 1982, Newell \& Field 1983, Wulff \& Field 1983). With down- 
welling, when NW winds typical of winter prevail, high quality particulates in the form of living phytoplankton and freshly fragmented kelp can be expected to move inshore. However, the summer SE winds give rise to upwelling which is accompanied by the blooming and movement of phytoplankton offshore (Andrews \& Hutchings 1980, Brown 1981, Barlow 1982a, b, Brown \& Hutchings 1987). Lower quality material, such as aged, fragmented kelp, as well as decaying phytoplankton, would then dominate inshore waters, thus giving rise to the observed decline in the organic content of rock-pool particulates.

Venerupis corrugatus displayed an ability to alter clearance rates, together with relative particle retention efficiencies, in response to tidal variability in both the particle spectrum and quantity of suspended material. At low tide, clearance rates and retention efficiencies were maximum in the particle diameter range of 5 to $9 \mu \mathrm{m}$, whereas at high water, peak clearance rates were 1.5 times higher and coincided, together with maximum retention efficiency, with the 8 to $13 \mu \mathrm{m}$ size fraction. These changes in feeding behaviour on the flood tide coincided with an increase in total resource biomass of $43 \%$ as well as an increase in the particle size range from a maximum diameter of around $12 \mu \mathrm{m}$ to between 17 and $21 \mu \mathrm{m}$.

The ability to regulate clearance rates in response to short-term changes in food availability is a common feature among bivalves (Bayne \& Newell 1983) and, as such, is predictable in Venerupis corrugatus. However, a change in the size of particles retained, with maximum efficiency coincident with short-term fluctuations in the relative concentration of such particles, has not previously been demonstrated to our knowledge. Such an adaptive ability on the part of $V$. corrugatus may necessitate rapid and continuous changes in the positioning of latero-frontal gill filaments and possibly gill ostia diameter so that, at low tide, smaller particles (5 to $9 \mu \mathrm{m}$ ) could be retained with the highest efficiency with a switch to maximum retention of larger particles ( 8 to $13 \mu \mathrm{m}$ ) at high tide. Indeed, the size of particles retained by bivalves is generally considered to be primarily a function of the spacing between laterofrontal cilia, while food concentration, together with the angle of ciliary beat, muscular expansion of the ostia and steep velocity gradients, also regulate particle retention efficiencies (Davids 1964, Dral 1967 , Jørgensen 1981, 1983, Jørgensen et al. 1986, 1988).

Whatever the mechanism by which maximum retention efficiency is regulated, the fact that it changed rapidly in direct response to a continually broadening particle spectrum is of great nutritional importance to Venerupis corrugatus. On exposure to larger and more abundant particles on the incoming tide, $V$. corrugatus increased gross ingestion of organic material by $65 \%$. Since there were proportionally more inorganic particulates at high tide $147 \%$ compared to $39 \%$ at low tide), the 'gross' ingested ration would inevitably include a greater fraction of particles of little lood value. Greater pseudofaeces production during experiments using water collected at high tide was direct evidence of increased particle rejection. Moreover the greater organic fraction in these pseudofaeces indicated that some potentially valuable food was unavoidably rejected together with less nutritious material. Nevertheless, even when account was taken of these losses, net organic intake at high tide still demonstrated a $39 \%$ increase over that at low tide.

The abundant production of pseudofaeces by bivalves filtering suspensions containing substantial amounts of silt is believed to be indicative of efficient preingestive selection. Such feeding behaviour, which is indicated in Venerupis corrugatus, ensures that by rejecting nutritionally poor particles as pseudofaeces, the food value of the ingested ration is increased (Jørgensen 1966, Kiørboe \& Møhlenberg 1981, Møhlenberg \& Kiørboe 1981, Newell \& Jordan 1983). Indeed Bricelj \& Malouf (1984) postulated that pre-ingestion selection is characteristic of those bivalve species which inhabit and exploit turbid environments such as the intertidal rock-pool at Bloubergstrand.

In conclusion it appears that Venerupis corrugatus makes maximum use of a natural resource which changes rapidly in its quantity, quality and spectrum of particle sizes within the short period of a tidal cycle. Superimposed on this tidal availability of food are further short-term changes imposed by the rapidity with which the quality of nearshore water masses can change (Field et al. 1981). On a time scale of days rather than seasonally, standing stocks of particulates, which are the most likely source of intertidal suspended material, are exported from or imported into inshore areas under the influence of swell height coupled with wind-induced upwelling or downwelling respectively. Thus, irrespective of season, Venerupis corrugatus is likely to experience constant short-term cycles of food availability within the intertidal zone of Bloubergstrand.

This is in sharp contrast to the long-term deprivation in food supply experienced on a seasonal basis by species inhabiting northern temperate regions. It has been found, for instance, that Mytilus edulis from southwest England displays long-term physiological adjustments, such as extensive build-up of body reserves, to cope with the stress of winter starvation (Hawkins \& Bayne 1984, 1985, Hawkins et al. 1985). Such feeding behaviour is believed to indicate timeaveraged rather than immediate optimisation of natural resources. It is tempting to postulate that longterm cycles of food availability, characteristic of dis- 
tinct geographical areas, may be a major factor determining the feeding strategy adopted by resident bivalve species. This topic will be addressed in a subsequent paper in which adjustments in the energy budget of Venerupis corrugatus to tidal food availability is investigated in the context of the energetic advantages of either immediate or time-averaged optimisation of natural resources.

Acknowledgements. We are grateful to Steve Webb for his help in the field and to Wayne Smith for identifying and counting bacteria. We also thank Prof Charles Griffiths for his valuable comments on the original manuscript. Financial support was provided by the South African Foundation for Research Development.

\section{LITERATURE CITED}

Amouroux, J M. (1986). Comparative study of the carbon cycle in Venus verrucosa fed on bacteria and phytoplankton. I. Consumption of bacteria (Lactobacillus sp.). Mar. Biol. 90: 237-241

Andrews, W. R. H., Hutchings, L. (1980). Upwelling in the southern Benguela current. Prog. Oceanogr. 9: 1-81

Barlow, R. G. (1982a). Phytoplankton ecology in the southern Benguela current. 1. Biochemical composition. J. exp. mar. Biol. Ecol. 63: 209-227

Barlow, R. G. (1982b). Phytoplankton ecology in the southern Benguela current. III. Dynamics of a bloom. J. exp. mar Biol. Ecol. 63: 239-248

Bayne, B. L. (1976). Marine mussels, their ecology and physiology. Cambridge University Press, London

Bayne, B. L., Hawkins, A. J. S., Navarro, E. (1987). Feeding and digestion by the mussel Mytilus edulis L. (Bivalvia, Mollusca) in mixtures of silt and algal cells at low concentrations. J exp. mar. Biol. Ecol. 111 1-22

Bayne, B. L., Hawkins, A. J. S., Navarro, E., Iglesias, I. P. (1989). Effects of seston concentration on feeding, digestion and growth in the mussel Mytilus edulis. Mar. Ecol. Prog. Ser. 55: 47-54

Bayne, B. L., Klumpp, D. W., Clarke, K. R. (1984). Aspects of feeding, including estimates of gut residence time, in three mytilid species (Bivalvia, Mollusca) at two contrasting sites in the Cape Peninsula, South Africa. Oecologia (Berl.) 64: 26-33

Bayne, B. L., Newell, R. C. (1983). Physiological energetics of marine molluscs. In: Saleuddin, A. S. M., Wilbur, K. M. (eds.) The Mollusca, Vol. 4, Physiology, Part 1. Academic Press, New York, p. 407-515

Bricelj, V. M., Malouf, R. E. (1984). Influence of algal and suspended sediment concentrations on the feeding physiology of the hard clam Mercenaria mercenaria. Mar. Biol. 84: 155-165

Brown, P. C. (1981). Pelagic phytoplankton, primary production and nutrient supply in the southern Benguela region. Trans. R. Soc. S. Afr. 44:347-355

Brown, P. C., Hutchings, L. (1987). The development and decline of phytoplankton blooms in the southern Benguela upwelling system. I. Drogue movements, hydrography and bloom development. In: Payne, A. I. L., Gulland, J. A.. Brink, K. H. (eds.) The Benguela and comparable ecosystems. S. Afr. J. mar. Sci. 5: 357-391
Clarke, B. C., Griffiths, C. L. (1990). Ecological energetics of mussels Choromytilus meridionalis under simulated intertidal rock pool conditions. J. exp. mar. Biol. Ecol. 137 $63-77$

Coughlan, J. (1969). The estimation of filtering rate from the clearance of suspensions. Mar Biol. 2: 356-358

Cuccl, I L., Shumway, S. E., Newell, R. C., Selvin, R., Guillard, R. R. L., Yentsch, C. M. (1985). Flow cytometry: a new method for characterisation of differential ingestion, digestion and egestion by suspension feeders. Mar Ecol. Prog. Ser. 24: 201-204

Davids, C (1964). The influence of suspensions of microorganisms of different concentrations on the pumping and retention of food by the mussel Mytilus edulis L. Neth. J. Sea Res. 2: 23-259

Day, J. H. (1974). A guide to marine life on South African shores, 2nd edn. A. A. Balkema, Cape Town

de Villiers, C. J., Allanson, B. R. (1988). Efficiency of particle retention in Solen cylindraceus (Hanley). Estuar. coast. Shelf Sci. 26: 421-428

Doetsch, R. N., Cook, T M. (1973). Introduction to bacteria and their ecobiology. University Park Press, Baltimore

Dral, A. D. G. (1967). The movements of the latero-frontal cilia and the mechanism of particle retention in the mussel Mytilus edulis L. Neth. J. Sea Res. 3: 391-422

Field, J. G., Griffiths, C. L., Linley, E. A. S., Zoutendyk, P., Carter, R. A. (1981). Wind-induced water movements in a Benguela kelp bed. In: Richards, F. A. (ed.) Coastal upwelling. American Geophysical Union, Washington, D.C., p. $507-513$

Criffiths, R. J. (1980). Natural food availability and assimilation in the bivalve Choromytilus meridionalis. Mar. Ecol. Prog. Ser. 3: 151-156

Griffiths, C. L., King, J. A. (1979). Some relationships between size, food availability and energy balance in the ribbed mussel Aulacomya ater. Mar. Biol. 51. 141-149

Griffiths, C. L., Griffiths. R. J. (1987). Bivalvia. In: Pandian, $T$ J., Vernberg, F. J. (eds.) Animal energetics. Academic Press, New York, p. 1-88

Hawkins, A. J S., Bayne, B. L. (1984). Seasonal variation in the balance between physiological mechanisms of feeding and digestion in Mytilus edulis (Bivalvia: Mollusca). Mar Biol. 82: 233-240

Hawkins, A. J. S., Bayne, B. L. (1985). Seasonal variation in the relative utilisation of carbon and nitrogen by the mussel Mytilus edulis: budgets, conversion efficiencies and maintenance requirements. Mar. Ecol. Prog. Ser. 25: 181-188

Hawkins, A. J. S., Salkeld, P. N., Bayne, B. L., Gnaiger, E., Lowe, D. M. (1985). Feeding and resource allocation in the mussel Mytilus edulis: evidence of time-averaged optimisation. Mar. Ecol. Prog. Ser. 20: 273-287

Hobbie, J. E., Daley, R. T., Jasper, S. (1977). Use of Nuclepore filters for counting bacteria by epifluorescence microscopy. Appl. environ. Microbiol. 33: 1225-1228

Jorgensen, C. B. (1966). Biology of suspension feeding. Pergamon Press, Oxford

Jorgensen, C. B. (1981). A hydromechanical principle for particle retention in Mytilus edulis and other ciliary suspension feeders. Mar. Biol. 61: 277-282

Jørgensen, C. B. (1983). Fluid mechanical aspects of suspension feeding. Mar. Ecol. Prog. Ser. 11: 89-103

Jørgensen, C. B., Larsen, P. S., Møhlenberg, F., Riisgård, H. U. (1988). The mussel pump: properties and modelling. Mar. Ecol. Prog. Ser. 45: 205-216

Jørgensen, C. B., Møhlenberg, F., Sten-Knudsen (1986). Nature of relation between ventilation and oxygen consumption in filter feeders. Mar. Ecol. Prog. Ser 29:73-88 
Kiørboe, T., Møhlenberg, F. (1981). Particle selection in suspension-feeding bivalves. Mar. Ecol. Prog. Ser. 5: 291-296

Kiørboe, T., Mohlenberg, F., Nohr, O. (1981). Effect of suspended bottom material on growth and energetics in Mytilus edulis. Mar. Biol. 61: 283-288

Linley, E. A. S., Newell, R. C., Bosma, S. A. (1981). Heterotrophic utilisation of mucilage released during fragmentation of kelp (Ecklonia maxima and Laminaria pallida). I. Development of microbial communities associated with the degradation of kelp mucilage. Mar. Ecol. Prog. Ser. 4 $31-41$

Lucas, M. I., Newell, R. C. \{1984\}. Utilisation of saltmarsh grass detritus by two estuarine bivalves: carbohydrase activity of crystalline style enzymes of the oyster Crassostrea virginica (Gmelin) and the mussel Geukensia demissa (Dillwyn). Mar. Biol. Lett 5: 275-290

Lucas, M. I., Newell, R. C., Shumway, S. E. Seiderer, L. J., Bally, R. (1987). Particle clearance and yield in relation to bacterioplankton and suspended particulate availability in estuarine and open coast populations of the mussel Mytilus edulis. Mar. Ecol. Prog. Ser. 36: 215-224

Luria, S. E. (1960). The bacterial protoplasm: composition and organisation. In: Gunsalus, I. C., Stainer, R. Y. (eds.) The bacteria, Vol. 1. Academic Press, New York, p. 1-34

Matthews, S., Lucas, M. I., Stenton-Dozey, J. M. E., Brown, A C. (1989). Clearance and yield of bacterioplankton and particulates for two suspension-feeding, infaunal bivalves, Donax serra Roding and Mactra lilacea Lam. J. exp. mar Biol. Ecol. 125: 219-234

Møhlenberg, F., Kiørboe, $T$ (1981). Growth and energetics in Spisula subtruncata (Da Costa) and the effect of suspended bottom material. Ophelia 20:79-90

Newell, R. C., Field, J. G. (1983). The contribution of bacteria and detritus to carbon and nitrogen flow in a benthic community. Mar. Biol. Lett. 4: 23-36

Newell, R. C., Field, J. G., Griffiths, C. L. (1982). Energy balance and significance of micro-organisms in a kelp bed community. Mar. Ecol. Prog. Ser. 8: 103-113

Newell, R. I. E., Jordan, S. J. (1983). Preferential ingestion of

This article was presented by $J$. G. Field, Rondebosch, South Africa organic material by the American oyster Crassostrea virginica. Mar. Ecol. Prog. Ser. 13: 47-53

Newell, R. I. E., Langdon, C. J. (1986). Digestion and absorption of refractory carbon from the plant Spartina alterniflora by the oyster Crassostrea virginica. Mar. Ecol. Prog. Ser. 34: 105-115

Painting, S. E., Lucas, M. I., Stenton-Dozey, J. M. E. (1985). Biomass and production of bacterioplankton in Prydz Bay, Antartica: phytoplankton, detritus and bacterial relationships. S. Afr. J. antarct. Res. 15: 42-52

Robinson, W. E., Wehling, W. E., Morse, M. P. (1984). The effect of suspended clay on feeding and digestive efficiency of the surf clam Spisula solidissima (Dillwyn). J. exp. mar. Biol. Ecol. 74: 1-12

Seiderer, L. J., Newell, R. C. (1985). Relative significance of phytoplankton, bacteria and plant detritus as carbon and nitrogen resources for the kelp bed filter-feeder Choromytilus meridionalis. Mar. Ecol. Prog. Ser. 22: 127-139

Shumway, S. E., Cucci, T L., Newell, R. C. Yentsch, C. M. (1985). Particle selection, ingestion and absorption in filter-feeding bivalves. J. exp. mar. Biol. Ecol. 91: 77-92

Stuart, V. (1982). Absorbed ration, respiratory costs and resultant scope for growth in the mussel Aulacomya ater (Molina) fed on a diet of kelp detritus of different ages. Mar. Biol. Lett. 3: 289-306

Stuart, V., Klumpp, D. (1984). Evidence for food-resource partitioning by kelp bed filter-feeders. Mar. Ecol. Prog. Ser. 16: $27-37$

Winter, J. E. (1978). A review of the knowledge of suspension feeding in lamellibranch bivalves, with special reference to artificial systems. Aquaculture 13: 1-33

Wright, R. T., Coffin, R. B., Ersing, C. P., Pearson, D. (1982). Field and laboratory measurements of bivalve filtration of natural marine phytoplankton. Limnol. Oceanogr. 27:91-98

Wulff, F. V., Field, J. G. (1983). Importance of different trophic pathways in a nearshore benthic community under upwelling and downwelling conditions. Mar. Ecol. Prog. Ser. 12: $217-228$

Zar, J. H. (1984). Biostatistical analysis, 2nd edn. Prentice Hill, Rondebosch

Manuscript first received: May 7, 1991

Revised version accepted: March 23, 1992 